\title{
The economic spillover of South Sumatera toward economic of Southern Sumatera Provinces in Indonesia
}

\author{
Fitri Kurniasih'; Taufiq Marwa²; Saadah Yuliana²; Abdul Bashir ${ }^{2 *}$ \\ 1) Central Bureau of Statistics, OKU Timur District, South Sumatera, Indonesia \\ ${ }^{2)}$ Department of Development Economics, Faculty of Economics, \\ Universitas Sriwijaya, Indonesia
}

*To whom correspondence should be addressed: Email: abd.bashir@unsri.ac.id

\begin{abstract}
This study to investigation effect of hinterland government expenditure each region, Gross Regional Domestic Product (GRDP), investment, consumer price index, and the road length of South Sumatera province toward the GRDP of other provinces in Southern Sumatera such as Jambi, Lampung, Bengkulu, and Bangka-Belitung Island. The data use secondary data during 1986-2015, data source from the Central Bureau of Statistics, Directorate General of Regional Fiscal Balance, and Indonesia Investment Coordinating Board. The analysis uses multiple regressions with Ordinary Least Square (OLS) method. The results showed that the economic spillover of South Sumatera consisting of gross domestic product, investment, consumer price index and the road length caused spread effects to Jambi, Lampung, Bengkulu, and Bangka Belitung with positive values except for Bangka Belitung whose consumer price index was negative.
\end{abstract}

Keywords: Economic spillover, Growth center, GRDP, Hinterland, Spread effect

JEL Classification: F43, O10, R10

\section{INTRODUCTION}

Development basically is a multidimensional process that involves changes in social structure, attitudes of society and national institutions. It also includes changes in the rate of economic growth, reduction in income inequality, and poverty eradication (Sinding, 2009). To achieve the desired objectives, the development of a country can be directed to three main things, namely increasing the availability and distribution of basic needs for the community, community living standards and the ability of the community to access, both economic and social activities (Todaro \& Smith, 2011).

Shanzi \& Feser (2010) found that spread-effect occurred in urban areas, while backwash-effect occurred in rural areas. Thus, it was illustrated that the impact of the Growth Center strategy differed across the hierarchy thus suggesting that the expected trickle-down effect around the growth center did not occur evenly. Furthermore, a study conducted by Basile, Capello \& Caragliu (2011) the results showed that the effect of geographic and relational proximity on knowledge spillovers strengthened one another; the data clearly showed that the immediate area in terms of spatial to exchange knowledge was easier when having the same level of confidence. 
In addition, the study conducted by Pasaribu (2015) showed that the spillover effect of growth centers in Kalimantan detected using the LM Spatial lag test significantly proved that there was regional dependence on output, labor, and investment growths. Simultaneous testing of their models proved that the major factors affecting all the three growths were spatial interactions with nearby growth centers. While multi-polarization test results between growth centers in and outside Kalimantan confirmed by spatio-temporal test on goods flow and passenger flow showed significant results. The polarization of the entry of goods in Kalimantan tended to be faster, as opposed to result for polarization of passenger flow to Kalimantan. These findings indicated that growth centers in Kalimantan had high demands for goods from outside their territory, while residents living in growth centers in Kalimantan were more likely to migrate to growth centers outside it.

The process of economic growth of a region is closely related to the geographic position between one region and another. The hypothesis of spread-backwash effect by Myrdal (1957) against geographic events and the spread of economic growth contribute to the development of regional economic studies as it attempts to explain the effects of growth spreading from the economic aspects (Chiang, 2018; Samimi \& Jenatabadi, 2014). The spread effect occurs when the growth of Gross Regional Domestic Product (GRDP) caused by the growth center has a positive coefficient meaning that the development of the region of growth center will increase the development of GRDP in hinterland area (Dholakia, 2009). Backwash effect occurs when the development of GRDP in the region of growth center makes a decrease in the development of hinterland GRDP reflected from negative coefficient. The interregional linkage in the economic field can be in the form of: flow of goods, intermediate goods, final goods, market links, production linkages, consumer shopping patterns, control patterns, economic ownership, income streams including remittance, capital flows, formal and informal financial systems, and labor migration (Bendavid-Val, 1991).

The economic development leads to a circular cause-effect process that makes the rich get more profits, and those left behind are hampered. Backwash effects tend to grow and spread effects tend to shrink (Myrdal, 1957). Cumulatively this trend is exacerbating international inequality and causing regional inequality among underdeveloped countries (Alvaredo \& Gasparini, 2013; Goda, 2016).

Positive influence on the development of the surrounding region is called the spread effect such as the opening of employment opportunities, the number of incoming investments, higher labor costs, and the population able to market the raw materials. Its negative effect is called backwash effect, like the emergence of regional imbalance (Chiang, 2018; Samimi \& Jenatabadi, 2014). The imbalance of this region occurs because the flow of interaction between the hinterland regions to the central region of growth is greater than the interaction flow from the central region of growth to the hinterland region. The real form of this phenomenon can be known from the large dependence of the village community on the central areas of growth.

Backwash effects and spread effects are unlikely to run in balance. First, much larger regional inequality occurs in the hinterland area. Secondly, in the suburbs, the regional inequality widened and the regions in the developed regions narrowed further. The higher the level of economic development that has been achieved an area, the stronger the spread effect will occur because the development is accompanied by 
transportation and communication and the level of education is getting better (Jhingan, 2012).

South Sumatera is a region with the greater potential to grow than other regions based on the value of Gross Regional Domestic Product at constant prices. South Sumatera has a GRDP value greater than other regions of Southern Sumatera meaning that the economic region that can be set as a growth center have excess factors that can affect the growth of the surrounding area.

Table 1. GRDP on the Basis of constant price 2010 (IDR. Billion) 2011-2015

\begin{tabular}{lrrrrr}
\hline Provinces & \multicolumn{1}{c}{$\mathbf{2 0 1 1}$} & \multicolumn{1}{c}{$\mathbf{2 0 1 2}$} & \multicolumn{1}{c}{$\mathbf{2 0 1 3}$} & \multicolumn{1}{c}{$\mathbf{2 0 1 4}$} & \multicolumn{1}{c}{$\mathbf{2 0 1 5}$} \\
\hline Jambi & $97,740.9$ & $104,615.1$ & $111,766.1$ & $119,984.7$ & $125,038.7$ \\
South Sumatera & $206,360.7$ & $220,459.2$ & $232,175.0$ & $243,093.8$ & $254,022.9$ \\
Bengkulu & $30,295.1$ & $32,363.0$ & $34,326.0$ & $36,206.7$ & $38,067.5$ \\
Lampung & $160,437.5$ & $170,769.2$ & $180,620.0$ & $189,790.0$ & $199,525.4$ \\
Bangka Belitung & $38,014.0$ & $40,104.9$ & $42,190.9$ & $44,159.4$ & $45,961.5$ \\
\hline
\end{tabular}

Source: Central Bureau of Statistics, Statistics Indonesia, 2016

In addition to the value of GRDP, South Sumatera province has a greater investment value compared to the provinces in Southern Sumatera. It shows that it is a destination province of domestic and foreign investors. With the increasing value of investment from year to year, as well as the construction of infrastructure such as the corridor of the eastern route of Sumatera, the development of Tanjung Api-Api port, the Tanjung Api-Api industrial estate, Inderalaya-Palembang-Betung toll road, and the role of South Sumatera as the food barn and energy in Sumatera, making South Sumatera a region that has the appeal to conduct economic activities. High investment value can affect the economic growth of a region, because of the multiplier effects resulting from such investment activities such as employment and an increase of flow of goods and services from one region to another.

Table 2. Realization of domestic and foreign investment of provinces in Southern Sumatera

\begin{tabular}{|c|c|c|c|c|c|c|c|c|c|c|}
\hline \multirow{2}{*}{ Provinces } & \multicolumn{2}{|c|}{2011} & \multicolumn{2}{|c|}{2012} & \multicolumn{2}{|c|}{2013} & \multicolumn{2}{|c|}{2014} & \multicolumn{2}{|c|}{2015} \\
\hline & DDI* & FDI*** & DDI* & FDI** & DDI* & FDI $* *$ & DDI* & FDI $* * *$ & DDI* & FDI $* * *$ \\
\hline Jambi & $2,134.80$ & 19.50 & $1,445.70$ & 156.30 & $2,799.60$ & 34.30 & 908.00 & 51.40 & 3.540 .00 & 107.70 \\
\hline South Sumatera & $1,068.90$ & 557.30 & $2,930.60$ & 786.40 & $3 ., 396.00$ & 485.90 & $7,042.80$ & $1,056.50$ & $10,944.10$ & 645.80 \\
\hline Bengkulu & 0.00 & 43.10 & 52.60 & 30.40 & 109.60 & 22.30 & 7.80 & 19.30 & 553.90 & 20.60 \\
\hline Lampung & 824.50 & 79.50 & 304.20 & 114.30 & $1,325.30$ & 46.80 & $3,495.70$ & 156.50 & 1.102 .30 & 257.70 \\
\hline BangkaBelitung & 514.40 & 146.00 & 533.50 & 59.20 & 608.20 & 112.40 & 615.50 & 105.00 & 1.023 .70 & 82.70 \\
\hline
\end{tabular}

Source: Central Bureau of Statistics, Statistics Indonesia in several years (processed)

Note: *Domestic Direct Investment (Billion IDR), **Foreign Direct Investment (Million U\$D)

Investment is an injection for the expansion of growth spread in a region through infrastructure development and other capital expenditures (Yuliana, Bashir, \& Rohima, 2019). The consideration is that investment is still a major supporting factor in driving growth in Indonesia (Soebyakto \& Bashir, 2017). The fulfillment of the need for the development of physical investment is strongly influenced by the need for raw materials, information, and technology from outside the region. The level of commodity prices in a certain region can affect the economic growth of the region through the working of interregional trade mechanisms (Marwa, Bashir, Adam, Azwardi, \& Thamrin, 2017; McCann, 2010). The price level is an economic variable that plays an important role and is a strategic economic variable because it can affect the workings of 
market mechanisms in an economy (Adam, Marwa, Azwardi, Thamrin, \& Bashir, 2017).

South Sumatera province is expected to be a province capable of performing functions and able to develop hinterland region. The spillover effect that emerges from economic activities conducted by South Sumatera province makes the region around the development centers namely Jambi, Bangka-Belitung Islands, Bengkulu and Lampung provinces will benefit from regional spillover. In addition, the benefits also come from interregional cooperation and interregional trade (changes in demand and supply influenced by the Consumer Price Index in South Sumatera Province) resulting in a beneficial effect due to the spillover effect of South Sumatera Province in the surrounding area called spread effect.

Interregional trade in Southern Sumatera provinces is supported by a country road length infrastructure owned by each province and the distance of district/cities among provinces connected by directly interconnected land routes, except the Bangka Belitung Islands province, which does not have a direct land route in the region of South Sumatera. Therefore this study to investigate the economic spillover effect such as government expenditure, Gross Regional Domestic Product, investment, consumer price index, and the road length of South Sumatera province toward the Gross Regional Domestic Products of other provinces in Southern Sumatera such as Jambi, Lampung, Bengkulu, and Bangka-Belitung Island.

\section{METHODS}

The scope of this study discussed the economic and investment conditions in the Southern Sumatera region covering the Province of South Sumatera as a growth center, while the hinterland areas consisted of Jambi, Lampung, Bengkulu, and BangkaBelitung Islands provinces. The types of data used in this study were secondary data i.e. publications from Central Bureau of Statistics (BPS), Bank Indonesia, Investment Coordinating Board (BKPM), Directorate General of Fiscal Balance (DJPK) and literature study in the form of articles, journals and other sources associated with this study. The data used were secondary data of 1986 to 2015 .

The descriptive method was conducted by presenting and compiling existing data into tables as information material to be analyzed using a qualitative approach. The method of quantitative analysis used to identify the economic spillover effect on economic of Southern Sumatera provinces use multiple regressions with Ordinary Least Square (OLS) method. Based on Richardson's regional income theory, the regression model was used to see the magnitude of the spillover effect of South Sumatera Province (Growth Center) to hinterland areas as follows:

$$
\operatorname{lnY} \mathrm{Y}_{\mathrm{h}}=\mathrm{a}_{0}+\beta_{1} \mathrm{PP}_{\mathrm{h}}+\beta_{2} \mathrm{Y}_{\mathrm{gs}}+\beta_{3} \mathrm{INV}_{\mathrm{gs}}+\beta_{4} \mathrm{IHK}_{\mathrm{gs}}+\beta_{5} \ln \mathrm{PJ} \mathrm{J}_{\mathrm{ss}}+\mathrm{e}_{1}
$$

Furthermore, for each regions, the semi-log models were used as follows:

$$
\begin{aligned}
& \ln \mathrm{Y}_{\mathrm{J}}=\mathrm{a}_{0}+\beta_{1} \mathrm{PP}_{\mathrm{J}}+\beta_{2} \mathrm{Y}_{\mathrm{gs}}+\beta_{3} \operatorname{lnINV}_{\mathrm{gs}}+\beta_{4} \mathrm{IHK}_{\mathrm{gs}}+\beta_{5} \ln \mathrm{PJ} \mathrm{J}_{\mathrm{ss}}+\mathrm{e}_{2} \\
& \ln \mathrm{Y}_{\mathrm{L}}=\mathrm{a}_{0}+\beta_{1} \mathrm{PP}_{\mathrm{L}}+\beta_{2} \ln \mathrm{Y}_{\mathrm{ss}}+\beta_{3} \ln \mathrm{INV}_{\mathrm{ss}}+\beta_{4} \mathrm{IHK}_{\mathrm{ss}}+\beta_{5} \ln \mathrm{PJ} \mathrm{J}_{\mathrm{ss}}+\mathrm{e}_{3} \\
& \ln \mathrm{Y}_{\mathrm{B}}=\mathrm{a}_{0}+\beta_{1} \mathrm{PP}_{\mathrm{B}}+\beta_{2} \mathrm{Y}_{\mathrm{ss}}+\beta_{3} \mathrm{INV}_{\mathrm{ss}}+\beta_{4} \operatorname{lnIHK}_{\mathrm{ss}}+\beta_{5} \ln \mathrm{PJ} \mathrm{J}_{\mathrm{ss}}+\mathrm{e}_{4} \\
& \ln \mathrm{Y}_{\mathrm{BB}}=\mathrm{a}_{0}+\beta_{1} \mathrm{PP}_{\mathrm{BB}}+\beta_{2} \mathrm{Y}_{\mathrm{gs}}+\beta_{3} \mathrm{INV}_{\mathrm{gs}}+\beta_{4} \mathrm{IHK}_{\mathrm{gs}}+\beta_{5} \mathrm{PJ}_{\mathrm{sg}}+\mathrm{e}_{5}
\end{aligned}
$$


where: $\mathrm{Y}_{\mathrm{h}}$ is GRDP of hinterland regions; $\alpha$ is $\alpha$ constants; $\beta$ is coefficient of parameters; $\mathrm{Y}_{\mathrm{J}}$ is GRDP of Jambi province; $\mathrm{Y}_{\mathrm{J}}$ is Government expenditure of Jambi province; $\mathrm{Y}_{\mathrm{L}}$ is GRDP of Lampung province; $\mathrm{PP}_{\mathrm{L}}$ is Government expenditure of Lampung province; $\mathrm{Y}_{\mathrm{B}}$ is GRDP of Bengkulu province; $\mathrm{PP}_{\mathrm{B}}$ is Government expenditure of Bengkulu province; $\mathrm{Y}_{\mathrm{BB}}$ is GRDP of Bangka-Belitung Island; $\mathrm{PP}_{\mathrm{BB}}$ is Government expenditure of Bangka-Belitung Island; $\mathrm{PP}_{\mathrm{h}}$ is hinterland regional government expenditure; $\mathrm{Y}_{\mathrm{SS}}$ is GRDP of South Sumatera; $\mathrm{INV}_{\mathrm{SS}}$ is Investment of South Sumatera; IHK $\mathrm{SS}$ is consumer price index of South Sumatera; $\mathrm{PJ}_{\mathrm{SS}}$ is road length of South Sumatera; e is error term.

\section{RESULTS AND DISCUSSION}

One of the most indicators commonly used to find out the economic condition of a region was the Gross Regional Domestic Product (GRDP). Within 30 years, the value of GRDP in South Sumatera increased very significantly; the highest increase of GRDP was achieved by South Sumatera province. According to business field at constant price, GRDP of South Sumatera province in 1986 was 4,249 billion rupiah and increased to 254,022.9 billion rupiah in 2015 .

During the period of 1986 until 2015 there was a change of economic sector contribution to the formation of GRDP South Sumatera. In 1986 the trade sector contributed the most with $22.95 \%$, agriculture sector with contribution of $21.58 \%$, manufacturing industry sector $20.53 \%$ and mining and quarrying sector by $18.43 \%$. While in 2015, sectors that contribute greatly to the economy of South Sumatera was the mining sector of $21.87 \%$, the manufacturing sector with a contribution of $18.27 \%$ and the agricultural sector by $16.5 \%$.

The rate of economic growth during the period of 30 years in South Sumatera has fluctuated. The rate of economic growth in 1986 grew by $4.60 \%$, during the period of 1986 to 2015, the highest economic growth rate occurred in 1992 reaching $9.29 \%$, while in 1998 the rate of economic growth contracted to minus $6.81 \%$. The monetary crisis that infected the Indonesian economy which began in 1997 peaked in 1998 resulted in all economic sectors in all parts of Indonesia decreased not an exception the area in southern Sumatera because of the rapidly evolving economic crisis developed into a multidimensional crisis including crises in the economic, political, social and even legal fields.

Economic sectors that were able to survive during the economic crisis were agriculture with the growth of $4.44 \%$, and electricity, gas and water sector grew by $4.83 \%$. Compared to the provinces of southern Sumatera, Lampung Province was the province with the lowest economic growth rate contraction in southern Sumatera in 1998 reaching minus $6.95 \%$, Bengkulu province minus $6.27 \%$ and Jambi province minus 5.41\%, while in the year 1998 Province of Bangka Belitung Islands was still incorporated with the Province of South Sumatera.

The estimation results of this study in Table 3 indicated that estimation result of each region, first, Jambi province (Eq.2) showed that the value of $\mathrm{R}^{2}$ was 0.8810 meaning that $88.10 \%$ of GRDP Jambi Province could be explained by the variables of Jambi Provincial Government Expenditure $\left(\mathrm{PP}_{\mathrm{J}}\right)$, GRDP of South Sumatera Province $\left(\mathrm{Y}_{\mathrm{SS}}\right)$, South Sumatera Provincial Investment $\left(\mathrm{INV}_{\mathrm{SS}}\right)$, Consumer Price Index of South 
Sumatera province $\left(\mathrm{IHK}_{\mathrm{SS}}\right)$ and road length of South Sumatera province $\left(\mathrm{PJ}_{\mathrm{SS}}\right)$, while $11.9 \%$ were explained by other variables not included in the estimation model.

The second, Lampung province (Eq. 3) the estimation result show that the value of $\mathrm{R}^{2}$ was 0.9958 meaning that $99.58 \%$ GRDP of Jambi province could be explained by the variables of Lampung Provincial Government Expenditure $\left(\mathrm{PP}_{\mathrm{L}}\right)$, GRDP of South Sumatera province $\left(\mathrm{Y}_{\mathrm{SS}}\right)$, South Sumatera Provincial Investment $\left(\mathrm{INV}_{\mathrm{SS}}\right)$, consumer price index of South Sumatera province $\left(\mathrm{IHK}_{\mathrm{SS}}\right)$ and road length of South Sumatera province $\left(\mathrm{PJ}_{\mathrm{SS}}\right)$, while $0.42 \%$ was explained by other variables not included in the estimation model.

Table 3. The model estimation result

\begin{tabular}{|c|c|c|c|c|c|}
\hline \multirow[b]{2}{*}{ Model } & \multirow[b]{2}{*}{ Descriptions } & \multicolumn{4}{|c|}{ Model Estimation of Region } \\
\hline & & Jambi & Lampung & Bengkulu & $\begin{array}{l}\text { Bangka } \\
\text { Belitung }\end{array}$ \\
\hline $\mathbf{C}$ & Constant & $\begin{array}{l}-13.91392 \\
{[-1,62769]}\end{array}$ & $\begin{array}{c}-0.12968 \\
{[-0,33054]}\end{array}$ & $\begin{array}{c}3.70596 \\
{[5,88813]^{* *}}\end{array}$ & $\begin{array}{c}15.27708 \\
{[10.35596]^{* *}}\end{array}$ \\
\hline $\mathbf{P P}$ & $\begin{array}{l}\text { Government } \\
\text { expenditure of } \\
\text { hinterland each } \\
\text { region }\end{array}$ & $\begin{array}{c}0.00078 \\
{[2,83689]^{* *}}\end{array}$ & $\begin{array}{c}0.00206 \\
{[2,29384]^{* *}}\end{array}$ & $\begin{array}{c}0.693093 \\
{[12,2327]^{* *}}\end{array}$ & $\begin{array}{c}0.08411 \\
{[4.72406]^{* *}}\end{array}$ \\
\hline $\mathbf{Y}$ & $\begin{array}{l}\text { GRDP of South } \\
\text { Sumatera }\end{array}$ & $\begin{array}{c}0.00473 \\
{[3,16113]^{* *}}\end{array}$ & $\begin{array}{c}0.89100 \\
{[2,96232]^{* *}}\end{array}$ & $\begin{array}{c}0.00164 \\
{[2,57250]^{* *}}\end{array}$ & $\begin{array}{c}0.00281 \\
{[5.27125]^{* *}}\end{array}$ \\
\hline INV & $\begin{array}{l}\text { Investment of } \\
\text { South Sumatera }\end{array}$ & $\begin{array}{c}0.16751 \\
{[2,65985]^{* *}}\end{array}$ & $\begin{array}{c}0.00212 \\
{[4,07932]^{* *}}\end{array}$ & $\begin{array}{c}0.00458 \\
{[3,41031]^{* *}}\end{array}$ & $\begin{array}{c}0.00084 \\
{[8.70869]^{* *}}\end{array}$ \\
\hline IHK & $\begin{array}{l}\text { Consumer price } \\
\text { index of South } \\
\text { Sumatera }\end{array}$ & $\begin{array}{c}0.00454 \\
{[2,13943]^{* *}}\end{array}$ & $\begin{array}{c}0.001201 \\
{[3,11476]^{* *}}\end{array}$ & $\begin{array}{c}0.50182 \\
{[4,26008]^{* *}}\end{array}$ & $\begin{array}{c}-0.00309 \\
{[-3.92461]^{* *}}\end{array}$ \\
\hline PJ & $\begin{array}{l}\text { Road length of } \\
\text { South Sumatera }\end{array}$ & $\begin{array}{c}2.77906 \\
{[2,92725]^{* *}}\end{array}$ & $\begin{array}{c}0.00817 \\
{[6,05261]^{* *}}\end{array}$ & $\begin{array}{c}0.00311 \\
{[2,13923]^{* *}}\end{array}$ & $\begin{array}{c}0.00171 \\
{[2.31870]^{* *}}\end{array}$ \\
\hline $\begin{array}{l}R^{2} \\
\text { f-test }\end{array}$ & & $\begin{array}{c}0,881089 \\
{[43,97581]^{* * *}}\end{array}$ & $\begin{array}{c}0,995846 \\
{[139,1588]^{* * *}}\end{array}$ & $\begin{array}{c}0,987038 \\
{[442,6480]^{* * *}}\end{array}$ & $\begin{array}{c}0.961212 \\
{[75.3444]^{* * *}}\end{array}$ \\
\hline
\end{tabular}

The third, region of Bengkulu (Eq. 4) estimation result show that $\mathrm{R}^{2}$ was 0.9870 meaning that $98.70 \%$ of GRDP of Jambi province could be explained by the variables of Bengkulu Provincial Government Expenditure $\left(\mathrm{PP}_{\mathrm{B}}\right)$, GRDP of South Sumatera province $\left(\mathrm{Y}_{\mathrm{SS}}\right)$, South Sumatera Provincial Investment $\left(\mathrm{INV}_{\mathrm{SS}}\right)$, consumer price index of South Sumatera province $\left(\mathrm{IHK}_{\mathrm{SS}}\right)$ and road length of South Sumatera province $\left(\mathrm{PJ}_{\mathrm{SS}}\right)$, while $1.3 \%$ was explained by other variables not included in the estimation model.

The fourth, the estimation result of Bangka-Belitung Islands province (Eq. 5) showed that $\mathrm{R}^{2}$ was 0.9612 meaning that $96.12 \%$ of GRDP of Jambi province could be explained by the variables of Bangka-Belitung Islands Provincial Government Expenditure $\left(\mathrm{PP}_{\mathrm{BB}}\right)$, GRDP of South Sumatera province $\left(\mathrm{Y}_{\mathrm{SS}}\right)$, South Sumatera Provincial Investment $\left(\mathrm{INV}_{\mathrm{SS}}\right)$, consumer price index of South Sumatera province $\left(\mathrm{IHK}_{\mathrm{SS}}\right)$ and road length of South Sumatera province $\left(\mathrm{PJ}_{\mathrm{SS}}\right)$, while $3.88 \%$ was explained 
by other variables not included in the estimation model.

In Table 3 show government expenditure variables have positive sign and significant influence on all study regions. This shows that the government spending on study areas has an effect on economic growth. Regional government expenditures will encourage regional economic growth if local government spending is largely or wholly used to purchase products produced by economic actors in the area. This is in line with the study conducted by Suparta (2009) showing that government spending had a positive and significant impact. The coefficient of government expenditure in all study areas is inelastic meaning that GRDP is not sensitive to changes in government expenditure even though the development of government expenditures increases rapidly every year, especially Lampung and Jambi provinces which have higher government expenditures if compared to Bengkulu and Bangka-Belitung Islands Provinces.

GRDP of South Sumatera province $\left(\mathrm{Y}_{\mathrm{SS}}\right)$ has a positive and significant influence to the GRDP of Jambi $\left(\mathrm{Y}_{\mathrm{J}}\right)$, Lampung $\left(\mathrm{Y}_{\mathrm{L}}\right)$, Bengkulu $\left(\mathrm{Y}_{\mathrm{B}}\right)$ and Bangka-Belitung Islands $\left(\mathrm{Y}_{\mathrm{BB}}\right)$, so it can be concluded that the spillover effect of GRDP of South Sumatera province has a spread effect for hinterland area meaning that the increase in GRDP of South Sumatera province is also able to stimulate increase in GRDP of Jambi, Lampung, Bengkulu and Bangka-Belitung Islands. This is in line with the study conducted by Dholakia, (2009) which stated that regions with high GRDP will provide spread effects, it is also mentioned that the spread effect will be stronger if the economic activity of growth center and hinterland areas have a strong connection to the need of goods, services, and factors of production.

Investment variables show a positive and significant effect meaning that the investment of both domestic and foreign investment can encourage economic activity in South Sumatera region due to the absorption of labor and the increase of output that can increase the growth of GRDP. The result of this study is in line with Pasaribu (2015) showing that the investment variable has a positive and significant effect on output growth. The high level of investment, especially foreign investment, in addition to opening employment also allows the transfer of technology from developed countries that invest. Technology transfer is expected to improve the skill through information about the production process, method and company policy in producing goods and services. If information can be transferred properly, it will stimulate innovation and efficiency in the product produced, thus increasing productivity, GRDP growth, and long-term economic growth. Therefore, investment plays an important role in creating GRDP and regional economic growth. The consumer price index variable shows the positive and significant effect of price level working through the interregional trading mechanism. Price level through market mechanism can affect economic growth of a region.

The IHK elasticity coefficient is inelastic throughout southern Sumatera, meaning that changes in consumer price index in South Sumatera province are not sensitive to changes occurring in the hinterland GRDP. The value of the IHK coefficients on the regression equation indicates a negative sign in the Bangka-Belitung Islands Province, as some basic commodities for the needs of the province are still imported from South Sumatera Province consisting of basic goods (nine basic necessities, textiles, iodine, green beans, soybeans, and peanuts); and strategic goods (cement, fertilizer, and fuel), 
so that the increase of consumer price index has a negative effect on GRDP of BangkaBelitung Islands province, while Jambi, Lampung and Bengkulu provinces show positive sign. The variable of road length showed a positive and significant influence on all study areas. This showed that infrastructure in the form of road length in South Sumatera province can increase economic activity in the regions of Southern Sumatera. The movement of goods flow using land line has an important role in increasing interregional trade. The coefficient elasticity of road length is inelastic in Lampung, Bengkulu and Bangka-Belitung provinces, where as in Jambi Province it is elastic, this is supported by the distance between the capital regions of South Sumatera province closer to the provincial capital of Jambi if compared to other provinces of Southern Sumatera.

\section{CONCLUSIONS AND RECOMMENDATIONS}

\section{Conclusions}

This study indicated that government expenditure variable, gross domestic product, investment, consumer price index and road length of South Sumatera shows has positive and significant effect on Gross Regional Domestic Product of Jambi, Lampung and Bengkulu Provinces, only the consumer price index variables provide has negative and significant effect on Gross Regional Domestic Product of Bangka-Belitung Island province.

This implies that economic spillovers of South Sumatera consisting of government expenditure, Gross Regional Domestic Product, investment, consumer price index and road length has a spread effect to Jambi, Lampung, and Bengkulu provinces indicated by the value of Gross Regional Domestic Product of South Sumatera province, investment, consumer price index and road length with positive value, except in Bangka-Belitung Islands province with the value of consumer price index is negative. In addition, the economic development that occurred in the hinterland region is not only influenced by economic factors coming from the region itself but also from the outside region that is from South Sumatera province which acts as a growth center for regions in Southern Sumatera..

\section{Recommendations}

The study has recommendations for policymakers such as (1) improving interregional cooperation in Southern Sumatera through various economic activities, technology, and information transfer; (2) improving adequate supporting facilities and infrastructure such as improving the infrastructure of each hinterland region due to the existence of interdependence between regions in meeting the various needs in supporting economic activities; and (3) A necessary further study to find out the effect of boundary or shipping distance among study areas.

\section{REFERENCES}

Adam, M., Marwa, T., Azwardi, -, Thamrin, K. M. H., \& Bashir, A. (2017). Analysis of Rice Distribution in South Sumatera, Indonesia. International Journal of Economics and Financial Issues, 7(3), 166-171. Retrieved from http://dergipark.gov.tr/ijefi/issue/32021/354221

Alvaredo, F., \& Gasparini, L. (2013). Recent Trends in Inequality and Poverty in 
Developing Countries. In Atkinson, A.B. \& Bourguignon, F. (Eds), Handbook of Income Distribution (pp. 697-805). Amsterdam: Elsevier B.V. https://doi.org/10.1016/B978-0-444-59428-0.00010-2

Basile R., Capello R., Caragliu A. (2011) Interregional Knowledge Spillovers and Economic Growth: The Role of Relational Proximity. In Kourtit K., Nijkamp P., Stough R. (eds), Drivers of Innovation, Entrepreneurship and Regional Dynamics. Advances in Spatial Science (The Regional Science Series), (pp 21-43). Berlin, Heidelberg: Springer. https://doi.org/10.1007\%2F978-3-642-17940-2_2

Bendavid-Val, A. (1991). Regional and Local Economic Analysis for Practitioners. New York: Greenwood Publishing Group, Inc.

Chiang, S. (2018). Assessing the Merits of the Urban-Led Policy in China: Spread or Backwash Effect? $\quad$ Sustainability, 10(451), 14. https://doi.org/10.3390/su10020451

Dholakia, R. H. (2009). Regional Sources of Growth Acceleration in India. Economic and Political Weekly, 44(47), 67-74. Available at: https://www.jstor.org/stable/25663814

Goda, T. (2016). Global Trends in Relative and Absolute Income Inequality. Ecos de Economía: A Latin American Journal of Applied Economics, 20(42), 46-69. https://doi.org/10.17230/ecos.2016.42.3

Jhingan, M. L. (2012). Ekonomi Pembangunan dan Perencanaan. Jakarta: Raja Grafindo Persada.

Marwa, T., Bashir, A., Adam, M., Azwardi, \& Thamrin, K. M. . (2017). Market Integration of Agricultural Products. International Journal of Economics and Business Administration, 5(2), 69-82.

McCann, D. (2010). The Political Economy of the European Union. Cambridge: Polity Press. https://doi.org/10.1111/j.1468-5965.2011.02172_2.x

Myrdal, G. (1957). Economic Theory and Underdeveloped Regions. London, England: G. Duckworth.

Pasaribu, E. (2015). Dampak Spillover dan Multipolaritas Pengembangan Wilayah Pusat- Pusat Pertumbuhan di Kalimantan (Doctoral Dissertation). Institut Pertanian Bogor, Bogor.

Samimi, P., \& Jenatabadi, H. S. (2014). Globalization and Economic Growth: Empirical Evidence on the Role of Complementarities. PLoS ONE, 9(4), 1-7. https://doi.org/10.1371/journal.pone.0087824

Shanzi, K., \& Feser, E. (2010). Count on the growth pole strategy for regional economic growth? Spread-backwash effects in greater central China. Regional Studies, 44(9), 1131-1147. https://doi.org/10.1080/00343400903373601.

Sinding, S. W. (2009). Population, poverty and economic development. Phil. Trans. R. Soc. B, 364, 3023-3030. https://doi.org/10.1098/rstb.2009.0145

Soebyakto, B. B., \& Bashir, A. (2017). The Effect of Short-Term Aggregate Demand in Indonesian Economy: The Era of ASEAN Economic Community. Journal of Applied Economic Sciences, XII(2(48)), 594-605.

Suparta, I. . (2009). Spillover Effect Economy of DKI Jakarta and South Sumatra Provinces Against Economic Growth of Lampung Province (Spillover Effect Perekonomian Provinsi DKI Jakarta dan Sumatera Selatan terhadap Pertumbuhan Ekonomi Provinsi Lampung). Jurnal Ekonomi Pembangunan, 10(1), 32-48. 
Todaro, M. P., \& Smith, S. C. (2011). Economic Development in Third World (Pembangunan Ekonomi Dunia Ketiga). (Agus Darma, Ed.) (11th ed.). Jakarta: Erlangga Publisher.

Yuliana, S., Bashir, A., \& Rohima, S. (2019). The Effect of Investment Toward Economic Growth in The Local Economy. Jurnal Ekonomi Dan Studi Pembangunan, 11(1), 28-39. 